\title{
Upaya Meningkatkan Perencanaan Karir Siswa Melalui Bimbingan Karir dengan Penggunaan Media Modul
}

\author{
Twi Tandar Atmaja \\ SMP Negeri 6 Tegal \\ Jl. Cinde Kencana No 1 Tegalsari, Tegal Barat, Tegal, Jawa Tengah,Indonesia \\ twitandaratmaja@gmail.com
}

\begin{abstract}
One of the tasks the development of high school teenagers are prepared to face the world of work or career. This study aims to improve students' career planning through career guidance with the use of media modules in class XII IPA 2 MAN Wonokromo Bantul academic year 2013/2014. This research is action research. The subjects were taken in this study using purposive sampling as many as 12 students who have a low level of career planning. Methods of data collection using questionnaires and observation. Analysis of the data used using the formula t-test to see the differences between the mean pretest and posttest mean. The research shows students career planning class XII IPA 2 can be enhanced through the use of media career guidance module seen from the significant difference from the average prior to career guidance at 105.25 and after a mean of 122.50 and career guidance. It can be concluded "there is increasing career guidance, career planning through the use of media modules in class XII IPA 2 MAN Wonokromo Bantul academic year 2013/2014. The results of this study can be used as reference material for teachers bmbingan and counseling programming and media development of career counseling services to improve students' career planning.
\end{abstract}

Keywords: career planning, career guidance, media modules

Salah satu tugas perkembangan remaja SMA adalah memiliki kesiapan untuk menghadapi dunia kerja ataupun karir. Penelitian ini bertujuan untuk meningkatkan perencanaan karir siswa melalui bimbingan karir dengan penggunaan media modul pada siswa kelas XII IPA 2 MAN Wonokromo Bantul tahun ajaran 2013/2014. Penelitian ini merupakan penelitian tindakan kelas. Subyek yang diambil dalam penelitian ini menggunakan teknik purposive sampling yaitu sebanyak 12 siswa yang memiliki tingkat perencanaan karir rendah. Metode pengumpulan data menggunakan angket dan observasi. Analisis data yang digunakan menggunakan rumus t-test untuk melihat perbedaan rerata pretest dan rerata posttest. Hasil penelitian menunjukan perencanaan karir siswa kelas XII IPA 2 dapat ditingkatkan melalui bimbingan karir dengan penggunaan media modul yang dilihat dari adanya perbedaan yang signifikan dari rerata sebelum dilakukan bimbingan karir sebesar 105,25 dan setelah dilakukan bimbingan karir rerata sebesar 122,50. Sehingga dapat disimpulkan "ada peningkatan perencanaan karir melalui bimbingan karir dengan penggunaan media modul pada siswa kelas XII IPA 2 MAN Wonokromo Bantul tahun ajaran 2013/2014. Hasil penelitian ini dapat dijadikan sebagai bahan rujukan bagi guru bmbingan dan konseling dalam penyusunan program dan pengembangan media layanan bimbingan konseling karir untuk meningkatkan perencanaan karir siswa.

Kata kunci: perencanaan karir, bimbingan karir, media modul

\section{Pendahuluan}

Pengangguran merupakan salah satu permasalahan yang ada di Indonesia. Pengangguran yang begitu tinggi bisa membawa dampak negatif dan permasalahan kemiskinan. Kemiskinan sering menjadi peneyebab seseorang untuk melakukan tindakan kriminal, seperti mencuri ataupun penipuan. Dampak lain dari pengangguran secara psikologis adalah memicu bunuh diri karena tidak siap dengan keadaan yang dihadapi. Jika kondisi seperti ini terus berlangsung, timbul pertanyaan dimana letak pemahaman karir sebagai wadah untuk menunjang mencari pekerjaan dan seberapa siapkah untuk bersaing mendapatkan pekerjaan sesuai karir yang diinginkan agar mengurangi angka pengangguran di Indonesia.

Karir merupakan suatu keseluruhan kehidupan seseorang dalam perwujudan diri untuk menjalani hidup dan mencapai tujuan. Untuk mencapai tujuan tersebut, individu harus memiliki kekuatan yang dimiliki seperti penguasaan kemampuan dan aspek yang menunjang kesuksesan karir. Perencanaan karir merupakan salah satu aspek yang paling penting dalam perkembangan karir individu. Kecakapan dalam mengambil keputusan 
merupakan tujuan utama dalam perencanaan karir yang harus ditempuh oleh setiap individu.

Setiap orang mengharapkan langkah dalam menempuh karir bisa berjalan lancar dan sukses. Kesuksesan seseorang bisa diukur dengan melihat kesuksesan jenjang karir yang dimiliki. Sukses dalam karir bisa dirasakan dengan perasaan bangga mendapatkan pekerjaan yang diharapkan, penghasilan yang lebih, status sosial yang tinggi dan dihargai orang lain. Sebaliknya, jika seseorang gagal dalam menempuh karir akan merasa rendah diri dengan status pengangguran, tidak bisa mencukupi kebutuhan hidup, serta dikucilkan oleh masyarakat. Perencanaan karir yang matang saat sekolah bisa membantu seseorang untuk lebih mengenal dan memahami bakat dan minat yang dimiliki.Kemampuan merencanakan karir perlu dimiliki oleh setiap individu termasuk siswa di sekolah. Perencanaan karir yang dimiliki oleh siswa berguna untuk pemilihan jenis studi lanjut, dan pemilihan rencana pekerjaan. Upaya meeningkatkan perencanaan karir siswa di sekolah dapat ditempuh melalui layanan bimbingan dan konseling.

Dalam Undang-Undang Republik Indonesia tahun 2003 No 20 pasal 3 tentang Sistem Pendidikan Nasional menentukan bahwa bimbingan dan konseling sebagai bagian integral dari sistem pendidikan. Layanan bimbingan konseling di sekolah bertujuan untuk membantu mengoptimalkan perkembangan siswa dan membantu memcahkan permasalahan siswa dalam berbagai bidang pelayanan. Bidang layanan dalam bimbingan konseling terdri dari bidang pribadi, sosial, belajar, dan karir.

Layanan bimbingan karir selain memberikan respon pada masalah-masalah yang dialami siswa, juga bertujuan untuk membantu siswa memperoleh pengetahuan, sikap, dan ketrampilan dalam pekerjaan. Selain itu, bimbingan karir menitikberatkan pada perencanaan kehidupan seseorang dengan mempertimbangkan keadaan individu dengan lingkungan agar dapat memperoleh pandangan positif ke depan. Dengan demikian, bimbingan karir berperan penting dalam meningkatkan perencanaan karir siswa.

Remaja sebagai siswa di sekolah menengah, merupakan individu yang masih dalam tahap perkembangan dalam merencanakan karir. Menurut Feldman, Olds, dan Papalia (2009:17)
Masa remaja merupakan periode transisi antara masa anak- anak dan masa dewasa. Batasan usia tidak ditentukan dengan jelas, sehingga banyak ahli yang berbeda dalam penentuan rentang usia. Namun, secara umum dapat dikatakan bahwa masa remaja berawal dari usia 11 sampai dengan akhir usia belasan yaitu sekitar 20 tahun ketika pertumbuhan fisik dan perubahan lain berlangsung cepat, yang ditandai dengan ada perubahan baik secara biologis, kognitif, maupun psikososial. Dalam perkembangan jasmani remaja juga sudah akil balig dan melihat dari proses perkembangan karir seharusnya sudah memiliki kemampuan menentukan pilihan karir untuk masa depan.

Remaja SMA yang merupakan sekolah lanjutan tingkat atas adalah individu yang sudah dianggap dewasa dan bisa lebih siap untuk menghadapi dunia kerja ataupun karir. Akan tetapi, berhubungan dengan layanan bimbingan konseling di Indonesia, remaja SMA belum mendapatkan layanan secara optimal termasuk bimbingan karir, hal tersebut dikarenakan banyak sekolah yang masih memfokuskan semua usaha untuk menempuh Ujian Nasional dan menyampingkan fungsi layanan bimbingan konseling yang berakibat ketidaksiapan dalam pemahaman karir secara optimal.

Hasil penelitian Amin Budiman (2012) melaporkan bahwa; 90\% siswa SMA di Kabupaten Bandung menyatakan bingung dalam memilih karir untuk masa depan. Pada kenyataan, siswa SMA juga belum bisa mencapai tugas perkembangan karir. Siswa SMA masih ragu dan tidak memiliki kesiapan membuat keputusan karir yang tepat bagi masa depan. Fakta ini menyatakan bahwa banyak remaja mengalami kebimbangan, ketidaksiapan dan stres dalam pembuatan keputusan karir. Kurang peduli terhadap karir, serta pilihan atas dasar mengikuti teman jika terus dibiarkan akan mengakibatkan dampak negatif. Akibat dampak negatif tersebut adalah, pemilihan studi lanjut secara asal, dan pemilihan kerja tidak sesuai bakat, serta tanpa melihat kemampuan dalam diri individu akan menjerumuskan pada kegagalan karir.

Permasalahan dalam perencanaan karir juga terjadi pada siswa MAN Wonokromo Bantul. Minat siswa untuk melanjutkan studi sangat minim, secara keseluruhan cenderung untuk memilih bekerja. Namun, ketika ada pertanyaan 
"akan bekerja dimana dan kerja apa” mereka masih kebingungan, tidak memiliki jawaban pasti, dan hanya mengandalkan ketrampilan terbatas dengan pengetahuan dunia kerja yang minim. Selain itu, pemberian layanan bimbingan konseling yang diterima siswa belum optimal dikarenakan tidak ada jam reguler bimbingan konseling. Kenyataan ini dibuktikan dari hasil wawancara kepada delapan siswa dan informasi langsung dari tiga guru pembimbing pada hari Senin 14 Januari 2014 di MAN Wonokromo Bantul.

Berbagai hambatan dan permasalahan di atas menunjukkan pelaksanaan layanan bimbingan konseling MAN Wonokromo Bantul mengalami kendala karena belum mencapai hasil yang diharapakan. Dalam hal ini guru bimbingan konseling adalah unsur pokok yang bertanggung jawab terhadap pengembangan proses belajar dan perkembangan siswa. Upaya untuk mencapai hasil yang diharapkan adalah, guru pembimbing dituntut memiliki kreatifitas dalam memberikan layanan bimbingan pada siswa agar mencapai hasil yang optimal.

Kemampuan siswa dalam merencanakan karir harus diawali dengan kemampuan siswa dalam melakukan eksplorasi karir dari dalam dirinya. Menurut Purwanta (2012) Eksplorasi karier merupakan upaya untuk memahami karakteristik diri individu dan karakteristik lingkungan karier dalam berbagai setting karier dan budaya di mana karier berada. Tujuan dari eksplorasi karier bagi anak tidak lain adalah untuk memilah dan memilih berbagai informasi tentang diri dan lingkunggannya sehingga anak dapat menentukan pilihan yang tepat sesuai dengan karakteristik dirinya, yang pada gilirannya is akan mencapai kemandirian. Dengan demikian, dalam membantu meningkatkan perencanaan karir siswa, dapat diawali dengan memberikan berbagai informasi karir agar siswa dapat memilah dan memilih berbagai informasi tentang diri dan lingkunggannya sehingga siswa dapat merencanakan karir sesuai dengan karakteristik dirinya.

Penyediaan berbagai informasi karir bagi siswa dapat dilakukan oleh guru melalui bantuan media bimbingan. Media merupakan salah satu komponen yang penting dalam proses pemberian bimbingan. Penggunaan media bimbingan sangat diperlukan agar proses bimbingan antara guru pembimbing dan siswa dapat berjalan dengan baik, tidak membosankan, serta dapat merangsang keaktifan dan kreativitas siswa.

Yusuf (2009: 80) menyatakan bahwa program layanan bimbingan dan konseling tidak dapat berjalan efektif dalam melayani siswa dengan terprogram apabila kurang atau tidak didukung oleh faktor lain, salah satu faktor pendukung pelaksanaan program bimbingan konseling adalah layanan informasi yang merupakan proses bantuan yang diberikan kepada para siswa. Berbagai aspek kehidupan yang dipandang penting bagi mereka, baik melalui informasi langsung maupun tidak langsung (melalui media cetak maupun elektronik seperti : buku, modul, brosur, majalah,dan internet). Salah satu media yang dapat digunakan oleh guru pembimbing dalam layanan bimbingan dan konseling adalah penggunaan modul. Penggunaan modul sangat bermanfaat bagi guru maupun siswa MAN Wonokromo, mengingat fakta dilapangan jarang sekali ada proses bimbingan di kelas. Oleh karena itu diperlukan layanan media bimbingan konseling sebagai guru pengganti pembimbing dalam menyampaikan informasi layanan bimibingan kepada siswa.

Tujuan penggunaan modul adalah untuk membekali para siswa dengan pengetahuan tentang pendidikan, bidang pekerjaan, bidang pengembangan pribadi dan sosial agar mereka dapat belajar tentang lingkungan hidup dan mampu merencanakan kehidupan secara mandiri. Selain itu, untuk memberikan plihan kepada siswa dan memberikan kesempatan pada siswa untuk mengenal kekurangan dan kelebihan dalam pengetahuan karir yang dimilki. Meskipun siswa MAN Wonokromo Bantul belum mengenal secara menyeluruh fungsi dari media layanan bimbingan konseling, diharapkan dengan penggunaan media bimbingan dapat menarik minat siswa untuk lebih mengenal fungsi dari layanan bimbingan dan konseling di sekolah. Sehingga diharapkan siswa tertarik untuk berkonsultasi dengan guru pembimbing tentang permasalahan belajar dan hambatan terutama untuk merencanakan karir di luar jam pelajaran.

Berdasarkan kenyataan di atas maka peneliti tertarik untuk mengadakan penelitian mengenai upaya meningkatkan perencanaan karir melalui penggunaan modul pada siswa MAN Wonokromo Bantul tahun ajaran 2013/2014. Layanan 
bimbingan dan konseling melalui penggunaan modul belum pernah dilakukan terutama dalam meningkatkan perencanaan karir pada siswa. Dalam penelitian ini, peneliti ingin mengetahui bagaimana tingkat perencanaan karir siswa MAN Wonokromo Bantul sebelum dan sesudah mendapatkan layanan bimbingan karir dengan media modul. Informasi dari hasil penelitian ini dapat dijadikan sebagai bahan pertimbangan dalam pengembangan media layanan bimbingan dan konseling untuk meningkatkan perencanaan karir pada siswa tingkat sekolah menengah atas dan sederajat.

\section{Kajian Literatur}

\section{Remaja}

Remaja merupakan peralihan dari masa anakanak menuju dewasa. Santrock (2009:26) mengatakan bahwa remaja (adolescence) diartikan sebaga masa perkembangan transisi antara masa anak dan masa dewasa yang mencakup perubahan biologis, kognitif dan sosial-emosional. Sementara itu, menurut Yusuf (2009:11) mengatakan bahwa fase remaja merupakan masa terjadi banjir hormon, yaitu zatzat kimia yang sangat kuat, yang disekresikan oleh kelenjar-kelenjar endoktrin dan dibawa keseluruh tubuh oleh aliran darah. Pengertian masa remaja di atas dapat diambil kesimpulan bahwa remaja adalah masa transisi antara anakanak dan dewasa yang ditandai dengan perubahan fisik, kematangan organ seksual, perkembangan sosial dan psikologis, serta peralihan dari masa ketergantungan kepada orang lain menjadi individu yang lebih mandiri. Selain itu, siswa SMA dapat dikategorikan sebagai individu yang telah memasuki usia remaja awal, yaitu individu yang berada dalam rentang usia 12-21 tahun bagi wanita dan usia 13 -22 tahun bagi laki-laki.

Sekian banyak tugas perkembangan remaja (kira-kira usia 18 sampai dengan 24 tahun), yaitu tugas-tugas yang berkaitan dengan pekerjaan dan kehidupan keluarga merupakan tugas yang sangat banyak, sangat penting dan sangat sulit dihadapi serta diatasi. Proses perkembangan karir pada remaja tidak mudah untuk dilaksanakan, akan tetapi remaja diharuskan mampu dalam mengatur beberapa tugas yang berkaitan dengan karir remaja (siswa).

Menurut Elizabeth (Nurhayati, 2011:281) “tugas perkembangan pada masa remaja adalah menemukan kelompok sosial yang cocok dan menyesuaikan diri dengan perubahan yang terjadi dalam lingkungan sosial.” Seseorang bekerja karena ada sesuatu yang hendak dicapai dengan harapan bahwa aktivitas kerja yang dilakukan membawa kepada suatu perubahan dan keadaan yang lebih memuaskan.

Tugas utama perkembangan remaja menurut Hurlock (Yusuf, 2009:21-23) dipaparan sebagai berikut: 1) menerima fisiknya sendiri berikut keragaman kualitasnya; 2) mencapai kemandirian emosional dari orang tua atau figur-figur yang mempunyai otoritas; 3) mengembangkan keterampilan komunikasi interpersonal dan belajar bergaul dengan teman sebaya atau orang lain, baik secara individual maupun kelompok; 4) menemukan manusia model yang dijadikan identitasnya; 5) menerima dirinya sendiri dan memiliki kepercayaan terhadap kemampuannya sendiri; 6) memperkuat self-control (kemampuan mengendalikan diri) atas dasar skala nilai, prinsip-prinsip atau falsafah hidup (Weltanschauung); 7) mampu meninggalkan reaksi dan penyesuaian diri (sikap/perilaku) kekanak-kanakan; 8) memilih dan mempersiapkan karir (pekerjaan).

Berdasarkan pendapat diatas mengenai tugastugas perkembangan remaja peneliti lebih cenderung sependapat dengan pendapat Hurlock, karena perencanaan karir menitikberatkan pada tugas perkembangan point 5 dan 8 yaitu menerima diri sendiri dan memiliki kepercayaan terhadap kemampuan sendiri serta memilih dan juga mempersiapkan karir (pekerjaan). Alasan peneliti yaitu agar siswa mampu menumbuhkan motivasi dalam berkarir agar mencapai kepuasan dalam pencapaian karir siswa sendiri.

Kecintaan terhadap pekerjaan merupakan langkah awal untuk dapat menghargai diri dan pekerjaan, sehingga tujuan-tujuan yang hendak dicapai dapat menumbuhkan motivasi dan kepuasan dalam melakukan pekerjaan. Karakteristik konsep diri yang penting berkaitan dengan pekerjaan bagi remaja Arifin, 1986 (Nurhayati,2011:298-299) adalah: 1) memahami kondisi dan kemampuan fisik, seperti kesehatan, bentuk tubuh, penampilan fisik, kekuatan dan kelemahan fisik; 2) memahami potensi-potensi, seperti kemampuan akademik, bakat, minat yang berhubungan dengan pekerjaan yang ingin dikembangkan; 3) memahami dan 
menyadari sifat-sifat kepribadian, seperti watak, emosi, kemampuan intelektual dan social; 4) memahami kemampuan dalam memilih dan mengambil keputusan dalam berbagai situasi, kebutuhan dan persoalan yang dihadapi; 5) memahami nilai-nilai dan tanggung jawab serta implikasi etis dari setiap pilihan pekerjaan yang diambil.

Karir bagi remaja merupakan sesuatu yang secara sosial diakui sebagai cara untuk memenuhi kepuasan berbagai kebutuhan atau keinginan yang tidak terpuaskan secara penuh sebelum. Karir juga dapat mengembangkan perasaan ingin diakui dalam masyarakat untuk memperoleh sesuatu yang diinginkan dan mencapai tujuan hidup. Menurut Uman (2009:113), karakteristik perkembangan karir remaja sesuai dengan karakteristik perkembangan karir tahap ekplorasi (usia 15-24 tahun). Tahap ekplorasi ditandai dengan mulai melakukan penilaian diri (self examination), mencoba membagi berbagai peranan, serta melakukan penjelajahan pekerjaan atau vokasional baik di sekolah, pada waktu senggang, maupun melalui system magang. Level eksplorasi meliputi tiga sub tahap yaitu: 1) tahap tentatif (usia antara 15-17 tahun). Tahap ini dikarakteristikan dengan mulai dipertimbangkan aspek- aspek kebutuhan, minat, kapasitas, nilainilai dan kesempatan secara menyeluruh. Pilihan pada masa tentative ini mulai diusahakan untuk keluar dari fantasi, baik melalui diskusi, bekerja, maupun aktivitas lain; 2) tahap transisi (usia antara 18-21 tahun). Tahap ini dikarakteristikan dengan menonjol pertimbangan yang lebih realistis untuk memasuki dunia kerja atau latihan profesional serta berusaha mengimplementasikan konsep diri; 3) tahap mencoba (usia antara 22-24 tahun). Tahap ini dikarakteristikan dengan mulai ditemukan lahan atau lapangan pekerjaan yang dipandang cocok, serta mencoba sebagai sesuatu yang sangat potensial.

Pendapat lain dikemukakan oleh Muro \& Kottman (Suherman, 2009: 114-115) karakteristik perkembangan karir remaja adalah sebagai berikut: 1) pengetahuan diri, meliputi memperoleh pengetahuan tentang pentingnya konsep perkembangan karir, mengembangkan keterampilan untuk berinteraksi dengan orang lain, mengembangkan kesadaran tentang pentingnya perkembangan emosional, dan fisik dalam pengambilan keputusan karir; 2) pengembangan pendidikan kejuruan, meliputi mengembangkan kesadaran tentang pentingnya prestasi pendidikan untuk melihat peluang karir, mengembangkan kesadaran tentang hubungan belajar dengan pekerjaanm, memperoleh keterampilan untuk memahami dan menggunakan informasi karir dan memperoleh kesadaran bagaimana karir berhubungan dengan fungsi dan kebutuhan masyarakat; 3) perencanaan dan eksplorasi karir, meliputi mengembangkan kesadaran hubungan timbal balik antara peran hidup, gaya hidup dan karir, mengembangkan kesadaran perbedaan vokasional dan perubahan peran laki-laki dan perempuan.

Berdasarkan pemaparan pendapat di atas yang terkait dalam penelitian ini bahwa tahap-tahap perkembangan karir pada remaja yaitu: tahap tentatif, tahap realistis, tahap perkembangan (growth), tahap eksplorasi, dimana remaja tersebut berada pada rentang usia 15 sampai 17 tahun. Pada tahap ini seseorang mampu memilih alternatif jabatan walapun seseorang belum mampu untuk mengambil keputusan. Peneliti berharap siswa mampu memahami potensipotensi seperti kemamuan akademik, bakat, minat yang berhubungan dengan pekerjaan yang ingin dikembangkan. Maka dari itu perlunya bantuan guru BK dalam merencanakan karir siswa.

\section{Perencanaan Karir}

Perencanaan karir adalah sesuatu yang menyangkut masa depan dalam jangka panjang yang harus direncanakan sejak jauh hari. Merencanakan kemana seseorang ingin melangkah dan apa yang ingin dicapai. Berikut dijelaskan beberapa pengertian perencanaan karir berdasarkan beberapa ahli yaitu Parson dalam Winkel \& Hastuti (2010:408), Simamora (2011:504).

Frank Parson dalam Winkel \& Hastuti (2010:408) merumuskan perencanaan karir yaitu suatu cara untuk membantu siswa dalam memilih suatu bidang karir yang sesuai dengan potensi mereka, sehingga dapat cukup berhasil di bidang pekerjaan. Perencanaan karir perlu disiapkan sebelum siswa terjun secara langsung dalam dunia karir. Perencanaan karir didasarkan atas potensi yang dimiliki siswa sehingga tidak ada pertentangan antara karir yang dipilih dengan potensi yang ada pada diri siswa. 
Simamora (2011:504) mengemukakan bahwa perencanaan karier (career planning) adalah suatu proses dimana individu dapat mengidentifikasi dan mengambil langkah-langkah untuk mencapai tujuan- tujuan karir. Perencanaan karir melibatkan pengidentifikasian tujuan- tujuan yang berkaitan dengan karir dan penyusunan rencana-rencana untuk mencapai tujuan tersebut. Dalam proses perencanaan karir individu akan memperoleh pengetahuan tentang potensi yang ada pada diri yang meliputi keterampilan, minat, pengetahuan, motivasi, dan karakteristik yang digunakan sebagai dasar dalam pemilihan karir yang kemudian dilanjutkan dengan menentukan tahapan untuk bisa mencapai karir yang sudah dipilih.

Diteruskan pula oleh Imamora (2011:504) bahwa, perencanaan karier merupakan proses untuk, menyadari diri sendiri terhadap peluangpeluang, kesempatan-kesempatan, kendalakendala, pilihan-pilihan, dan konsekuensikonsekuensi, mengidentifikasi tujuan-tujuan yang berkaitan dengan karier, dan penyusunan program kerja, pendidikan, dan yang berhubungan dengan pengalaman-pengalaman yang bersifat pengembangan guna menyediakan arah, waktu, dan urutan langkah-langkah yang diambil untuk meraih tujuan karier. Berdasarkan pendapat di atas, maka dapat disimpulkan bahwa perencanaan karir merupakan suatu proses pemilihan sasaran karir serta cara atau tahapan untuk mencapai sasaran karir tersebut yang didasarkan atas potensi yang dimiliki. Sasaran karir yang dipilih merupakan pilihan siswa itu sendiri. Proses pemilihan sasaran karir harus mempertimbangkan potensi yang ada pada diri sendiri. Potensi yang dimaksud meliputi bakat, minat, kepribadian, kemampuan dalam diri siswa sendiri. Setelah siswa mampu menentukan sasaran karir kemudian dapat ditentukan cara-cara yang harus dilalui untuk meraih karir yang telah dipilih.

Suherman (2009: 116) mengatakan bahwa dalam aspek perencanaan karir terdiri dari indikator-indikator sebagai berikut : 1) mempelajari informasi karir. Informasi karir mencakup segala informasi yang terkait dengan karir. Informasi karir bisa didapatkan dari berbagai macam sumber, misal media elektronik, media cetak ataupun sumber yang bersangkutan secara langsung. Siswa yang memiliki perencanaan karir akan memanfaatkan Informasi yang telah didapat dari berbagai sumber untuk dipelajari sehingga setiap siswa memiliki pemahaman tentang karir; 2) membicarakan karir dengan orang dewasa. Siswa yang memiliki perencanaan karir akan mempunyai anggapan bahwa orang dewasa merupakan orang yang memiliki banyak pengalaman dan pengetahuan termasuk salah satu pengalaman dan pengetahuan tentang karir; 3) mengikuti pendidikan tambahan (kursus). Mengikuti kursus atau pendidikan tambahan diharapkan agar siswa memilki ketrampilan terkait dengan karir yang telah dipilih dalam perencanaan karir. Memiliki ketrampilan yang dibutuhkan dalam karir akan mempermudah siswa untuk dapat sukses dalam karir yang telah direncanakan; 4) berpartisipasi dengan kegiatan ekstrakurikuler. Siswa yang memiliki perencanaan karir akan memanfaatkan ekstrakurikuler di sekolah sebagai media untuk menambah ketrampilan yang akan digunakan dalam pencapaian karir yang sesuai dengan citacita setiap siswa. Siswa yang tidak memiliki perencanaan karir maka siswa akan bersikap cuek dan acuh serta mempunyai anggapan bahwa ekstrakurikuler tidak mendatangkan manfaat apapun; 5) mengikuti pelatihan-pelatihan terkait dengan pekerjaan yang diinginkan. Sama dengan pendidikan tambahan dan ekstrakurikuler, diharapkan dengan mengikuti pelatihan-pelatihan terkait dengan pekerjaan yang diinginkan maka akan menambah ketrampilan yang ada pada diri siswa serta peningkatan pengetahuan tentang karir; 6) mengetahui kondisi pekerjaan yang diinginkan. Siswa yang memiliki perencanaan karir maka akan mempunyai rasa ingin tahu yang tinggi tentang kondisi pekerjaan yang diinginkan. Siswa bisa memanfaatkan berbagai media serta berbagai sumber informasi untuk mengetahui kondisi pekerjaan yang diinginkan. Beberapa sumber antara lain media elektronik, cetak, maupun orang yang sudah berpengalaman dan memiliki pengetahuan tentang karir; 7) mengetahui persyaratan pendidikan untuk karir yang diinginkan. Untuk memasuki karir maka dibutuhkan syarat-syarat tertentu.

Salah satu dari syarat memasuki karir adalah syarat pendidikan. Secara umum tuntutan pendidikan akan diberlakukan untuk memasuki karir tertentu; 8) dapat merencanakan apa yang harus dilakukan setelah tamat dari sekolah. 
Siswa yang mempunyai perencanaan karir pasti sudah ada perencanaan dalam diri terkait tentang langkah yang harus dilakukan setelah lulus dari sekolah. Setelah lulus dari sekolah maka siswa akan melakukan hal-hal yang bermanfaat bagi karir. Kegiatan-kegiatan yang dilakukan oleh siswa akan terarah pada kegiatan yang akan menunjang kesuksesan karir yang telah direncanakan siswa; 9) mengetahui cara dan kesempatan memasuki karir yang diinginkan. Salah satu tujuan dari perencanaan karir adalah untuk bisa mencapai kesuksesan karir di masa depan. Untuk mencapai kesuksesan karir maka siswa harus mampu mengetahui cara memasuki karir yang diinginkan. Sehingga siswa yang memiliki kemampuan perencanaan karir pasti memiliki pengetahuan tentang cara dan kesempatan untuk memasuki karir yang diinginkan; 10) mengatur waktu luang secara efektif.

Siswa yang memiliki kemampuan perencanaan karir, maka siswa akan memanfaatkan waktu yang ada dengan sebaik mungkin. Salah satu dari siswa yang memiliki perencanaan karir yaitu siswa akan mampu mengatur waktu luang secara efektif. Waktu luang yang ada akan digunakan untuk kegiatankegiatan yang bermanfaat bagi karir yang telah direncanakan.

Menurut Jordan (Yusuf, 2009:27) aspekaspek dalam perencanaan karir meliputi: 1) pemahaman karier adalah membantu pribadi untuk mengembangkan kesatuan dan gambaran diri serta peranan dalam dunia kerja; 2) mencari informasi, siswa yang memiliki perencanaan karir akan memanfaatkan informasi yang telah didapat dari berbagai sumber untuk dipelajari sehingga setiap siswa memiliki pemahaman tentang karir; 3) perencanaan dan pengambilan keputusan, merupakan suatu proses untuk menentukan langkah-langkah yang akan dilakukan dalam karir untuk mencapai tujuan yang telah ditetapkan. Berdasarkan ciri-ciri tersebut, siswa yang tidak memiliki ciri- ciri seperti yang telah disebutkan dapat dikatakan sebagai siswa yang tidak memiliki perencanaan karir sehingga perlu diberikan bantuan agar siswa tersebut bisa merencanakan karir setelah lulus dari jenjang pendidikan Sekolah Menengah Atas.

\section{Bimbingan Karir}

Bidang pekerjaan sangat bermakna bagi setiap individu, oleh karena itu bimbingan dan konseling di sekolah memberikan pemahaman pada siswa melalui bimbingan karir. Menurut Winkel \& Hastuti (2006: 623) bahwa bimbingan karir atau bimbingan jabatan merupakan salah satu wujud upaya pendidikan karir atau pendidikan jabatan, dan harus sama-sama berorierntasi pada pendampingan proses perkembangan karir manusia muda. Pendidikan jabatan itu sendiri mempunyai makna sebagai usaha dalam lingkungan pendidikan sekolah dan masyarakat luas untuk membantu semua individu untuk mengenal bidang-bidang jabatan yang terbuka dan memberikan makna positif pada kehidupan. Bimbingan karir yang dimaksud Winkel \& Hastuti merupakan sebuah kegiatan untuk mencapai tujuan dari pendidikan jabatan.

Peran bimbingan konseling di sekolah sangat penting dalam memberikan layanan bimbingan karir dengan menyediakan berbagai program studi sebagai persiapan untuk memasuki dunia pekerjaan. Pendapat lain yang dikemukakan Walgito (2010: 203) berpendapat bahwa bimbingan karir merupakan usaha untuk mengetahui dan memahami diri, memahami apa yang ada dalam diri sendiri dengan baik, serta untuk mengetahui dengan baik pekerjaan apa saja yang ada dan persyaratan apa yang dituntut untuk pekerjaan itu. Siswa dapat memadukan apa yang dituntut oleh suatu pekerjaan atau karir dengan kemampuan atau potensi yang ada dalam diri individu. Tingkatan pendidikan pun menjadi salah satu aspek penting sebagai faktor penentu terhadap pilihan jenis pekerjaan.

Lebih lanjut, bimbingan karir menurut Suherman (2011: 39) menyatakan bahwa bimbingan karir didefinisikan sebagai aktivitas-aktivitas dan program yang memabantu individu untuk mengasimilasikan dan mengintegrasikan pengetahuan, pengalaman, dan aspirasi-aspirasi yang berkaitan dengan pengenalan diri, pemahaman/ pengenalan terhadap kerja masyarakat dan faktor-faktor yang mempengaruhi perubahannya, kesadaran akan waktu luang, pemahaman akan perlunyadan banyaknya faktor yang harus dipertimbangkan dalam perencanaan karier, pemahaman terhadap informasi dan keterampilan yang diperlukan untuk mencapai pemenuhan diri dalam pekerjaan 
dan waktu luang, mempelajari dan menerapkan proses pengambilan keputusan karir. Berdasarkan uraian di atas, dapat disimpulkan bahwa bimbingan karir merupakan program-program pemberian bantuan yang dilakukan oleh guru pembimbing terhadap siswa untuk mengoptimalkan potensi dalam mempersiapkan diri menghadapi dunia pekerjaan. Salah satu persiapan itu yaitu menempuh jenjang pendidikan atau yang relevan dalam persiapan memilih lapangan pekerjaan atau jabatan/profesi tertentu. Untuk dapat melakukan persiapan tersebut diperlukan langkah awal, di antaranya yaitu dengan melakukan perencanaan karir yang menjadi salah satu tujuan dari bimbingan karir.

\section{Modul sebagai Media Layanan Bimbingan dan Konseling}

Menurut Miarso (Mustaji \& Nursalim, 2010: 6) media adalah segala sesuatu yang dapat digunakan untuk menyalurkan pesan yang dapat merangsang pikiran, perasaan, perhatian, dan kemauan siswa untuk belajar. Pengertian media tersebut dapat dijadikan sebagai stimulus bagi siswa untuk merangsang pikiran, perasaan, perhatian, dan antusias dalam menerima pesan yang berhubungan dengan layanan bimbingan dan konseling. Sukiman (2012 : 29) berpendapat bahwa media pembelajaran adalah segala sesuatu yang dapat digunakan untuk menyalurkan pesan dari pengirim ke penerima sehingga merangsang pikiran, perasaan, perhatian, dan minat serta kemauan peserta didik sedemikian rupa sehingga proses belajar terjadi dalam rangka mencapai tujuan pembelajaran secara efektif.

Pemberian layanan yang kreatif dan inovatif pada siswa akan meminimalisir kejenuhan dan kebosanan siswa dalam mengikuti layanan bimbingan dan konseling, menambah antusias tersendiri bagi siswa dalam mengikuti dan memaknai layanan bimbingan. Mustaji dan Nursalim (2010: 14) mendefinisikan bahwa modul yaitu suatu paket program yang disusun dalam bentuk satuan tertentu dan didesain sedemikian rupa guna memperlancar pelaksanaan layanan informasi dan bimbingan klasikal. Dalam bimbingan dan konseling modul seperti ini sering digunakan dalam modul bimbingan karir, bimbingan belajar dan sebagainya.

Menurut Sukiman (2012: 131) modul merupakan jenis kesatuan kegiatan belajar yang terencana, dirancang untuk membantu para pesarta didik secara individual dalam mencapai tujuan-tujuan belajarnya. Tujuan belajar dalam penelitian ini adalah dapat membantu siswa untuk meningkatkan perencanaan karir. Berdasarkan beberapa uraian tentang pengertian modul di atas, dapat disimpulkan bahwa modul sebagai media layanan bimbingan konseling, terutama bidang karir diharapkan membantu siswa ada peningkatan perencanaan karir.

Bimbingan karir melalui penggunaan modul disini merupakan layanan yang berupa pemberian pemahaman kepada siswa tentang berbagai plihan untuk menjalani tugas dan kegiatan di sekolah dan untuk menentukan serta mengarahkan tujuan hidup. Pemberian layanan ini dalam meningkatkan pemahaman merencanakan karir yang diharapkan dapat membantu siswa dalam mengambil keputusan untuk masa depan. Menurut Andi Prastowo (2011: 106) mengemukakan bahwa peserta didik dapat mengukur sendiri tingkat penguasaan mereka terhadap materi yang dibahas dalam setiap satu satuan modul, sehingga apabila telah menguasai, maka mereka dapat melanjutkan pada satu satuan modul tingkat lebih lanjut. Sebaliknya, jika belum menguasai, maka mereka harus mengulangi dan mempelajari kembali.

\section{Metode Penelitian}

Penelitian ini menggunakan metode penelitian tindakan kelas. Dalam satu siklus terdiri dari empat tahapan yaitu perencanaan, pelaksanaan, pengamatan, dan refleksi Subyek yang diambil dalam penelitian ini menggunakan teknik purposive sampling yaitu sebanyak 12 siswa yang memiliki tingkat perencanaan karir rendah. Instrumen yang digunakan yaitu berupa metode angket dan observasi. Penelitian secara keseluruhan dilaksanakan pada tanggal 18 Desember 2013 sampai dengan 25 januari 2014 yang bertempat di MAN Wonokromo Bantul. Layanan melalui penggunaan modul ini dilaksanakan 6 kali pertemuan yaitu pada tanggal 13,16,18, 20,23, 25 Januari 2014. Analisis data yang digunakan menggunakan rumus t-test untuk melihat perbedaan rerata pretest dan rerata posttest. 


\section{Hasil Penelitian dan Pembahasan}

Pengujian hipotesis yang diajukan dalam penelitian adalah ada peningkatan pemahaman perencanaan karir melalui penggunaan modul pada siswa kelas XII MAN Wonokromo Bantul Tahun Ajaran 2013/2014. Skor angket perencanaan karir pre test dan post test dianalisis menggunakan bantuan komputer dengan program SPSS (Statistical Package for Social Sciens) sebagaimana untuk melihat peningkatan perencanaan karir siswa melalui modul. Berdasarkan hasil analisis diperoleh deskripsi data variabel perencanaan karir melalui modul, dapat dilihat pada tabel 1 .

Tabel 1

Deskripsi Data Variabel Perencanaan Karir Sebelum dan Setelah diberi Layanan

\begin{tabular}{lllll}
\hline No Nama & $\begin{array}{c}\text { Skor } \\
\text { Sebelum } \\
\text { Bimbingan } \\
\text { (pre test) }\end{array}$ & $\begin{array}{l}\text { Skor Setelah } \\
\text { Bimbingan } \\
\text { (post test) }\end{array}$ & $\begin{array}{c}\text { Gain } \\
\text { Skor (d) }\end{array}$ \\
\hline 1 & AS & 108 & 121 & 13 \\
2 & AN & 101 & 117 & 16 \\
3 & BS & 107 & 120 & 13 \\
4 & CPK & 107 & 123 & 16 \\
5 & DSN & 96 & 129 & 33 \\
6 & EY & 103 & 124 & 21 \\
7 & IM & 108 & 113 & 5 \\
8 & MB & 106 & 126 & 20 \\
9 & R & 105 & 124 & 19 \\
10 & SK & 108 & 123 & 15 \\
11 & YIF & 108 & 128 & 20 \\
12 & ZA & 106 & 122 & 16 \\
Jumlah & 1263 & 1470 & 207 \\
Mean & 105,25 & 122,50 & 17,25 \\
\hline
\end{tabular}

Berdasarkan deskripsi data perencanaan karir melalui penggunaan modul, maka dapat diketahui bahwa setelah diberi layanan mengalami kenaikan rata-rata. Berikut deskripsi secara umum dapat dilihat pada tabel 2
Tabel 2

Deskripsi Skor Variabel Perencanaan Karir

\begin{tabular}{ccllllll}
\hline No & \multicolumn{2}{c}{ Perencanaan Skor } & Skor & Mean & Median SD \\
& Karir & Min & Max & & & \\
\hline 1 & $\begin{array}{c}\text { Sebelum } \\
\text { bimbingan } \\
\text { (pre test) }\end{array}$ & 96 & 108 & 105,25 & 106,50 & 3,64 \\
2 & $\begin{array}{c}\text { Setelah } \\
\text { bimbingan } \\
\text { (post test) }\end{array}$ & 113 & 129 & 122,50 & 123 & 4,46 \\
\hline
\end{tabular}

Peningkatan perencanaan karir yang signifikan dengan membandingkan antara pre test dan post test. Pengujian hipotesis menggunakan bantuan komputer SPSS mengetahui koefisien $\mathrm{t}$ hitung sebesar 9,082 selanjutnya diadakan pengujian terhadap tabel nilai-nilai distribusi t dengan taraf signifikan $5 \%$ untuk dk (n-1) 12-1= 11 adalah 1,796. Hal ini menunjukkan bahwa nilai t hitung lebih besar dari t tabel yaitu 9,082 > 1,697 atau $\mathrm{p}=0,00(\mathrm{p}<$ $0,05)$. Berarti ada perbedaan yang signifikan antara peningkatan pemahaman perencanaan karir sebelum dan sesudah diberi layanan melalui penggunaan modul.

Dengan demikian maka hipotesis nihil (Ho) yang diajukan berbunyi "tidak ada peningkatan pemahaman perencanaan karir melalui penggunaan modul pada siswa kelas XII MAN Wonokromo Bantul tahun ajaran 2013/2014” Ditolak. Sedangkan hipotesis alternatif (Ha) "ada peningkatan pemahaman perencanaan karir melalui penggunaan modul pada siswa kelas XII MAN Wonokromo Bantul tahun ajaran 2013/2014" teruji kebenarannya. Peningkatan perencanaan karir siswa sebelum diberi tindakan (pre test) dan setelah diberi tindakan (post test) juga dapat disajikan dalam bentuk gambar. Gambar 1 menunjukkan peningkatan perencanaan karir siswa sebelum dan sesudah diberi tindakan melalui penggunaan modul. 


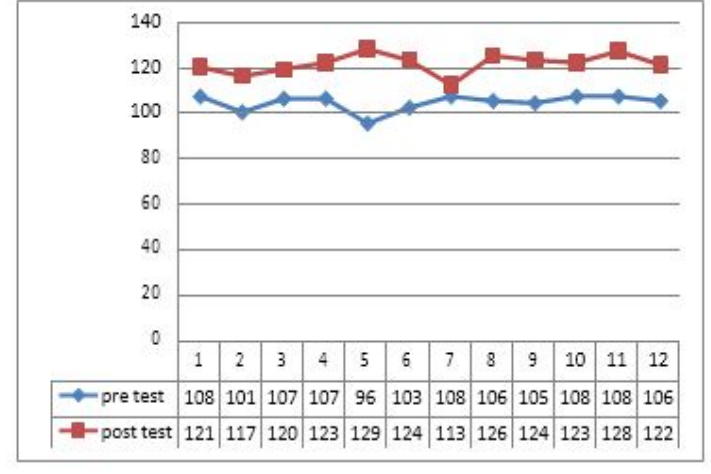

Gambar 1

Peningkatan Perencanaan Karir Siswa Sebelum Dan Sesudah Diberi Layanan melalui Penggunaan Modul

Perencanaan karir siswa sebelum dan sesudah diberi layanan menunjukkan adanya peningkatan skor perencanaan karir sebelum diberi tindakan (pre test) dan sesudah diberi tindakan (post test). Sebelum diberi layanan melalui penggunaan modul semua siswa berada pada kategori sedang sebanyak 12 siswa, setelah diberi layanan melalui penggunaan modul terjadi peningkatan perencanaan karir menjadis semua siswa berada pada kategori tinggi dengan jumlah 12 siswa.

Meningkatnya pemahaman perencanaan karir dapat diketahui dari hasil observasi dan pemberian angket pre test dan post test pemahaman perencanaan karir. Meningkatnya pemahaman perencanaan karir berdasarkan pemberian angket pre test dan post test menunjukkan sebelum diberi tindakan semua berada pada kategori sedang sebanyak 12 siswa $100 \%$, setelah diberi layanan terjadi peningkatan pemahaman perencanaan karir menjadi semua siswa berada pada kategori tinggi sebesar $100 \%$.

\section{Simpulan}

Berdasarkan hasil yang diperoleh dari analisis data dan pembahasan, maka dapat disimpulkan “pelaksaanaan layanan menggunakan modul dapat meningkatkan pemahaman perencanaan karir pada siswa kelas XII IPA 2 MAN Wonokromo Bantul Tahun Ajaran 2013/2014”. Ditunjang dari hasil observasi yang disesuaikan dengan hasil angket perencanaan karir dapat disimpulkan bahwa siswa yang mengalami peningkatan skor dalam lembar observasi juga mengalami peningkatan skor dalam angket post test perencanaan karir. Dengan kata lain semakin tinggi skor dalam lembar observasi, semakin tinggi pula pemahaman perencanaan karir siswa tersebut. Informasi dari hasil penelitian ini dapat dijadikan sebagai bahan pertimbangan dalam pengembangan media layanan bimbingan dan konseling untuk meningkatkan perencanaan karir pada tingkat sekolah menengah atas dan sederajatnya.

\section{Referensi}

Amin, Budiman. (2002). Manajemen Bimbingan Karir pada SMU di Kabupaten Bandung. Jurnal Psikolog Pendidikan dan Bimbingan vol.2 November 2002. 259-266.

Feldman, R.D., Olds, S.W. \& Papalia, D.E. (2009). Human Development (perkembangan manusia) Jakarta: Salemba Humanika.

Mochamad Nursalim \& Muastaji. (2010). Media Bimbigan dan Konseling. Surabaya : Unesa Univevity Press.

Prastowo, Andi. (2011). Panduan Kreatif Membuat Bahan Ajar Inovatif. Yogyakarta : DIVA Press.

Purwanto, Edi. (2012). Peran Kecerdasan Emosional dan Eksplorasi Anak. PSIKOPEDAGOGIA Jurnal Bimbingan dan Konseling, 1(1): 7-13.

Santrock, John W. (2009). Psikologi Pendidikan. Jakarta: Salemba Humanika.

Simamora, Henry. (2011). Manajemen Sumber Daya Manusia. Yogyakarta :YKPN.

Sukiman. (2012) Pengembangan Media Pembelajaran. Yogyakarta: Pedagogia

Suharsimi, Arikunto. (2010). Prosedur Penelitian: Suatu Pendekatan Praktik. Jakarta : Rineke Putra.

Syamsu, Yusuf. (2009). Program Bimbingan dan Konseling Di Sekolah. Bandung: Rizki Press.

Uman, Suherman. (2009). Konseling Karir Sepanjang Rentang Kehidupan. Bandung : UPI.

Walgito, B. (2010). Bimbingan Dan Konseling (Studi Karier). Yogyakarta: Andi.

Winkel, W. S \& Hastuti, S. (2010). Bimbingan dan Konseling di Institusi Pendidikan. Yogyakarta: Media Abadi. 
ATMAJA 